\title{
PERANCANGAN PIRANTI LUNAK RESPONSIVE UNTUK MONITORING RUANGAN SERVER MENGUNAKAN NODEMCU ESP8266 BERBASIS INTERNET OF THINGS
}

\author{
M. Safii ${ }^{1}$, Novi Indrayani ${ }^{2}$ \\ Dosen Universitas Mulia ${ }^{1,2}$ \\ Jl. Letjend. TNI. Z.A Maulani No. 9 Damai, Bahagia, Balikpapan Kota \\ Sur-el : safii@ universitasmulia.ac.id ${ }^{1}$, novi@ universitasmulia.ac.id ${ }^{2}$
}

\begin{abstract}
The role of the server is very important as a data service provider and control for an office that has a very large data usage and control system. This can also affect the temperature in the server room which has computer devices and other control systems because of its continuous use. The impact of temperature that is outside of its tolerance value due to the dead air conditioner without being noticed by the officer or server operator can result in damage to the hardware devices in the server room. Monitoring and measuring server room temperature is not possible to be done directly and accurately in all conditions due to several inhibiting factors in obtaining temperature information. With these problems, a temperature monitoring prototype was built using node MCU ESP 2866 and DHT 21 sensor with responsive web-based software so that it can be easily seen on various PC and smartphone monitors. This software can be used in server rooms to provide room temperature information to operators or server officers. The long-term objective of this research is expected to provide information Real-time temperature conditions in a responsive web-based server room.
\end{abstract}

Keywords: monitoring, software, responsive, nodeMcu

\begin{abstract}
Abstrak : Peran server sangat penting sebagai penyedia layanan data dan kontrol bagi sebuah kantor yang memiliki penggunaan data dan sistem kontrol yang sangat besar. Hal ini juga dapat berpengaruh terhadap suhu di dalam ruang server yang memiliki perangkat komputer dan sistem kontrol lainya di karenakan penggunaanya yang berjalan secara terus menerus. Dampak suhu yang di luar dari nilai toleransinya dikarenakan oleh pendingin ruangan yang mati tanpa di ketahui oleh petugas atau operator server dapat berakibat kerusakan pada perangkat hardware yang berada didalam ruang server tersebut. Pada kenyataannya monitoring serta pengukuran suhu ruang server tidak mungkin dilakukan secara langsung dan akurat pada semua kondisi yang disebabkan beberapa factor penghambat dalam memperoleh informasi suhu. Dengan permasalahan tersebut, maka dibangun sebuah prototype monitoring suhu menggunakan nodeMcu ESP 2866 dan sensor DHT 21 dengan piranti lunak berbasis web responsive sehingga dapat mudah di lihat diberbagai layar monitor PC maupun smartphone. Piranti lunak ini dapat digunakan pada ruang server untuk memberikan informasi suhu ruangan kepada operator atau petugas server. Tujuan jangka panjang dari penilitian ini diharapkan dapat memberikan sebuah informasi keadaan suhu yang real time di dalam ruang server berbasis web responsive.
\end{abstract}

Kata kunci: monitoring, piranti lunak, responsive, nodeMcu

\section{PENDAHULUAN}

Suhu merupakan salah satu hal utama yang sangat berpengaruh terhadap kelancaran dan kualitas suatu jaringan dalam server. Salah satu kendala yang sangat berpengaruh adalah naiknya tingkat suhu pada server. Suhu yang tinggi dapat mempengaruhi kinerja dari perangkat server, dikarenakan aktifitas server menghasilkan suhu panas yang mana jika tidak di turunkan maka bisa berakibat terkendalanya aktifitas server atau bahkan bisa merusak perangkat server itu sendiri. Maka perlu adanya sebuah perangkat monitoring suhu server agar dapat selalu diawasi setiap saat. 
Pada kenyataanya monitoring ruang server masih tidak dapat dilakukan secara langsung dan akurat pada kondisi tertentu dikarenakan berbagai faktor berbagai faktor yang mempengaruhi, seperti kendala sumber daya manusia dan letak geografis daerah ruang server tersebut. Faktor- faktor ini bisa jadi sebagai salah satu penghambat untuk dapat memonitoring ruang server secara realtime.

Rancangan penelitian ini bertujuan khusus membuat sebuah piranti lunak yang dapatmengukur suhu serta mengirimkan informasi suhu tersebut kepada operator server secara rutin dan melalui piranti lunak tersebut dapat merekam informasi suhu tersebut dan dapat membuat sebuah laporan berkala. Dimana dengan laporan tersebut dapat dijadikan dasar untuk melakukan evaluasi terhadap kinerja pendingin ruangan yang ada di dalam sever. Dengan adanya sistem monitoring tersebut maka diharapkan suhu pada server dapat selalu terjaga dan mengurangi resiko akan terjadi nya overheat, disebabkan oleh suhu server yang panas pengaruh dari pendingin ruangan yang rusak atau kinerja pendinginan ruangan yang kurang optimal. Standar pengelolaan data center menurut Rancangan Peraturan Menteri Komunikasi dan Informatika Republik Indonesia Tahun 2018 tentang Pedoman Teknis Pusat Data adalah memiliki minimal satu sensor temperatur ruang (Republik Indonesia, Menteri Komunikasi dan Informatika Republik, 2018) [1].

Langkah- langkah untuk mewujudkan penelitian ini mengikuti tahapan sesuai dengan metode studi pustaka mulai dari mengumpulkan data dan informasi, konsep yang bersifat teori, jurnal. Kemudian dari data-data yang telah di peroleh disusun untuk merancang perangkat keras untuk dilakukan pengujian dengan program yang telah dibuat [2]. Selanjutnya ketahapan pembuatan piranti lunak untuk digabungkan dengan perangkat keras untuk menjadi sebuat piranti lunak utuh yang mampu memonitoring suhu ruangan server secara real time.

\section{METODOLOGI PENELITIAN}

\subsection{Perkembangan IoT (Internet of Things)}

Di kutip dari Source : Forbes Insighht Amerika, Internet of Things (IoT) dipercaya sebagai satu teknologi yang makin memengaruhi kinerja bisnis berbagai lini kegiatan organisasi. Transformasi digital dimungkinkan dengan memanfaatkan teknologi ini. Industry 4.0, Intelligent Transportation System dan Smart City adalah bidang yang memanfaatkan IoT sebagai enabler nya. [3][4]

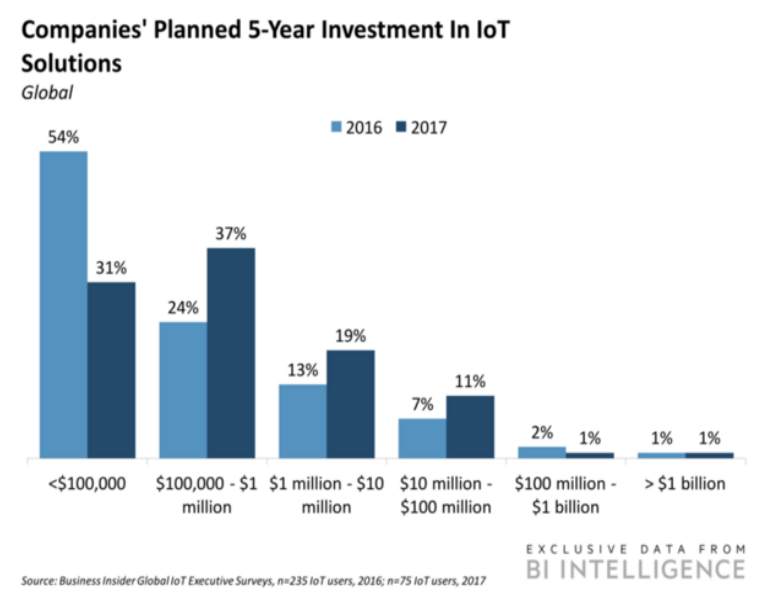

Gambar 1. User Percentage of Internet of Things

Survei yang dilakukan oleh Forbes Insight di Amerika Serikat pada 2017 lalu mengungkap, 33 persen responden mengatakan bahwa IoT merupakan teknologi terpenting bagi 
perusahaan. Bahkan lebih penting dibandingkan Robotika (26 persen), Artificial Intelligence (20 persen), serta Nano-Technologies (9 persen) [5][6].

\subsection{Sensor Suhu dan Kelembaban}

Didalam buku panduan Aosong temperature and humidity DHT22 digital capacitive relative humidity dan temperature sensor modul [7] di jelaskan bahwa sensor suhu dan kelembapan seperti DHT-22 memiliki kelebihan sebagai berikut:

1. Keluaran sudah berupa sinyal digital dengan konversi dan perhitungan dilakukan oleh MCU 8-bit terpadu

2. Sensor terkalibrasi secara akurat dengan kompensasi suhu di ruang penyesuaian dengan nilai koefisien kalibrasi tersimpan dalam memori OTP terpadu

3. (DHT-22) lebih akurat dan presesi dibanding DHT-11)

4. Rentang pengukuran suhu dan kelembapan yang lebih lebar mampu mentrasmisikan sinyal keluaran melewati kabel yang panjang (hingga 20 meter) sehingga cocok untuk ditempatkan dimana saja.

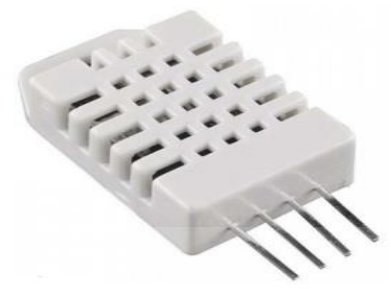

\section{Gambar 2. Sensor suhu dan kelembaban} DHT22

\subsection{NodeMcu ESP 8266}

NodeMcu merupakan sebuah opensource platform IoT dan pengembangan Kit yang menggunakan bahasa pemrograman Lua untuk membantu programmer dalam membuat prototype produk IoT atau bias dengan memakai sketch dengan arduino IDE. Pengembangan Kit ini didasarkan pada modul ESP8266, yang mengintegrasikan GPIO, PWM (Pulse Width Modulation), IIC , 1-Wire dan ADC (Analog to Digital Converter) semua dalam satu board. Keunikan dari Nodemcu ini sendiri yaitu Boardnya yang berukuran sangat kecil yaitu panjang $4.83 \mathrm{~cm}$, lebar $2.54 \mathrm{~cm}$, dan dengan berat 7 gram [8]. Tapi walaupun ukurannya yang kecil, board ini sudah dilengkapi dengan fitur wifi dan firmwarenya yang bersifat opensource.

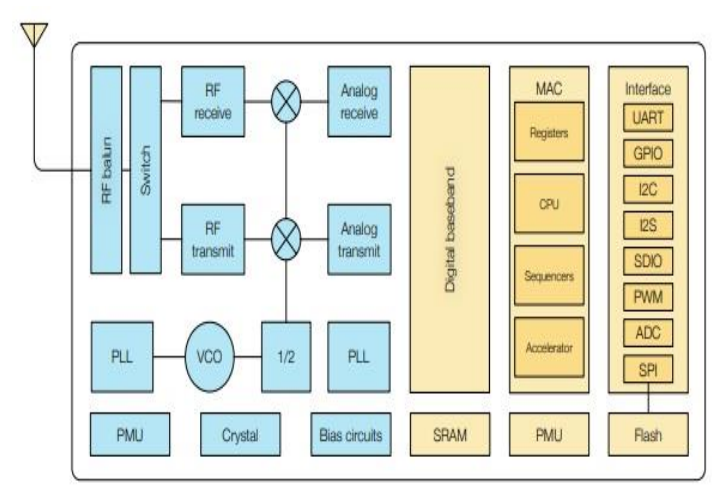

\section{Gambar 3. Functional blok diagram nodeMCU Esp 8266}

\subsection{Software Arduino}

Software Arduino yang digunakan adalah driver dan IDE, walaupun masih ada beberapa software lain yang sangat berguna selama pengembangan Arduino [10]. IDE atau Integrated Development Environment merupakan suatu program khusus untuk suatu komputer untu dapat membuat suatu rancangan 
atau sketsa program untuk program Arduino. IDE Arduino merupakan software yang sangat canggih ditulis dengan menggunakan java. IDE Arduino terdiri dari:

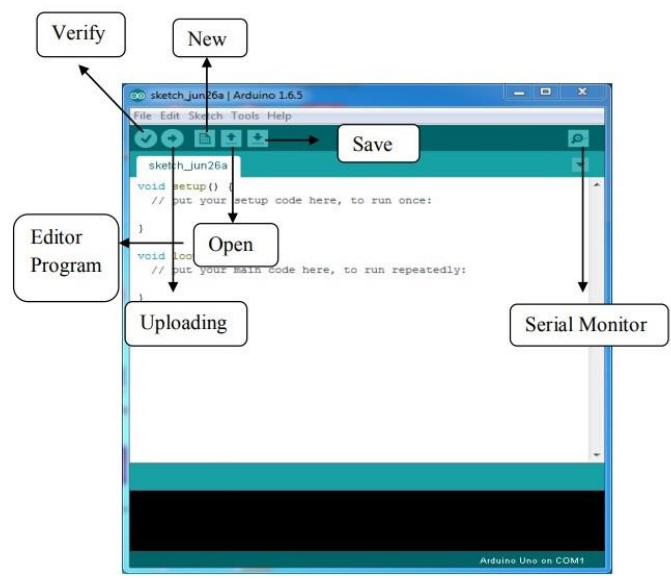

Gambar 4. Software Arduini IDE

\section{$2.5 \quad$ XАMPP}

Xampp adalah software yang berfungsi menjalankan sebuah website berbasis php dan menggunakan pengolahan data mysql. fungsi xampp adalah yang berdiri sebagai server yang berdiri sendiri (localhost), yang terdiri atas program Apache, http server, MySQL, database dan penterjemah bahasa yang ditulis dengan bahasa pemograman PHP dan Perl.[9]

\subsection{Metode Penelitian}

Konsep metodologi penelitian yang dilakukan adalah melakukan pendekatan solusi berbasis tujuan (Studi literatur), identifikasi masalah dan motivasi, penentuan fokus dari penelitian,perancangan dan pengembangan solusi, pembuatan simulasi, pengujian, pembahasan, yang diusulkan. pengambilan kesimpulan. Pendekatan ini menggunakan konsep yang diperkenalkan oleh Ken Peffers, Tuure Tuunanen, Marcus A. Rothenberger, dan
Samir Chatterjee pada jurnal berjudul "A Design Science Research Methodology for Information Systems Research". Bagan alir dapat dilihat pada gambar 6 tentang konsep metode Design Science Research (DSR) [10]

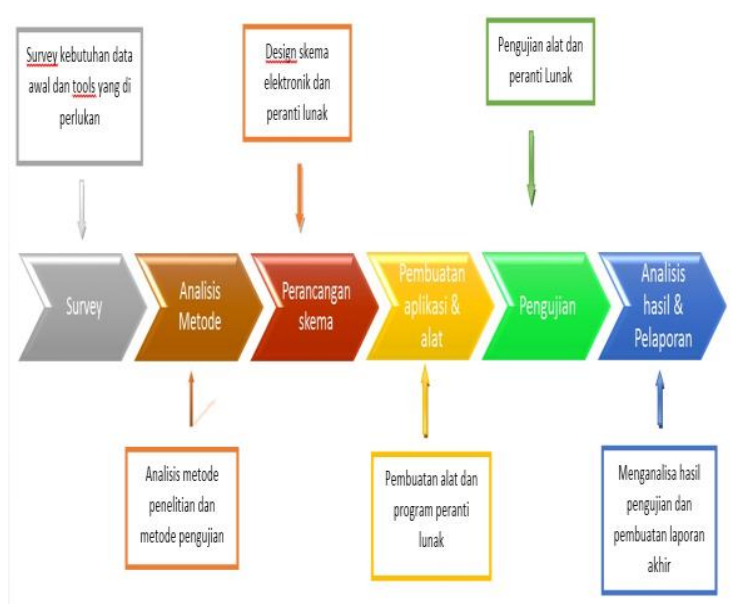

Gambar 5. Konsep Metode Penelitian

Penjabaran metode yang digunakan berdasarkan tahapan penelitian adalah sebagai berikut:

1. Analisi kebutuhan perangkat keras Analisis dilakukan untuk mencari ketersediaan komponen-komponen dan aplikasi pendukung apa saja yang di perlukan dalam penelitian.

2. Analisi metode perancangan dan pengujian

Penentuan fokus ditentukan berdasarkan hasil identifikasi masalah dan motivasi yang mendorong dilakukannya penelitian. Pembuatan proposal dilakukan sebagai pedoman dalam melakukan penelitian.

3. Perancangan skema elektronik dan perancangan mekanik di buat berdasarkan fokus dari penelitian yang akan dikerjakan dengan metode pengembangan prototype. 
4. Pembuatan alat dan program arduino Merangkai dang menghubungkan semua alat yang telah ditentukan sesuai dengan skema perangcangan.

5. Pengujian

Setelah rancangan dan demonstrasi/ simulasi didapatkan, pengujian terhadap prototype dilakukan untuk dievaluasi sekaligus menilai pencapaian tujuan. Pengujian prototype yang dilakukan pada ruang server universitas mulia.

6. Analisis dan Pelaporan

Analisis dilakukan terhadap hasil pengujian yang didapatkan. Analisis bertujuan memberikan gambaran kondisi prototype dan masukan mengenai arah pengembangan lebih lanjut.

\subsection{Teknik Pengumpulan Data}

Metode pengumpulan data merupakan teknik atau cara yang dilakukan untuk mengumpulkan data [11]. Pada penelitian ini peneliti menggunakan metode pengumpulan data dengan cara:

1. Obrservasi merupakan teknik pengumpulan data dengan langsung terjun ke lapangan untuk mengamati permasalahan yang terjadi secara langsung di tempat kejadian secara sistematik kejadian-kejadian, perilaku, objek-objek yang dilihat dan hal-hal lain yang diperlukan dalam mendukung penelitian yang sedang berlangsung.

2. Wawancara merupakan teknik pengumpulan data yang dilakukan melalui tatap muka dan tanya jawab langsung antara pengumpul data terhadap narasumber/sumber data. Adapun sumber data peneliti yaitu para pegawai dan vendor genset tersebut.

3. Studi Literatur adalah salah satu metode pengumpulan data dengan cara membaca bukubuku dan jurnal sesuai dengan data yang dibutuhkan. Pada penelitian ini penulis memilih studi literatur untuk mengumpulkan referensi dari buku-buku mengenai mikrokontroler serta jurnal yang membahas tentang mikrokontroler.

\section{HASIL DAN PEMBAHASAN}

\subsection{Diagram Blok Sistem}

Dalam perancangan dan pembuatan alat untuk peranti lunak monitoring suhu ruangan server menggunakan NodeMCU ESP 8266 sebagai mikrokontroller dan IoT. Dari hasil pembaca sensor DHT 22 disimpan melalui Web server untuk kemudian dapat dimonitoring oleh operator ruangan server. Pembuatan alat dibedakan dalam beberapa blok fungsi gambaran umum mengenai sistem kerja dan pembagian blok sistem dari penelitian ini ditunjukkan pada gambar 6.

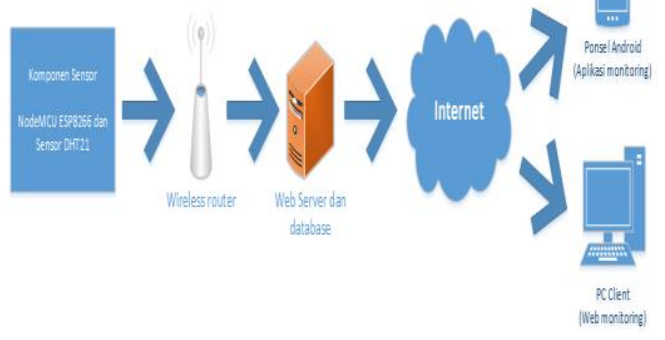

Gambar 6. Diagram blok sistem 


\subsection{Diagram Skema Elektronik}

Hasil rangkain skema elektronik menggunakan nodemcu esp 2866, Sensor DHT 22 dan Resistor nilai 2W 0,1 K Ohm. Untuk pin Out dari sensor DHT 22 di hubungkan ke pin D2 pada nodeMcu. Pin Negatif ke gnd dan pin vcc ke 3v pada nodeMcu. Untuk lebih jelasnya bisa melihat gambar 7 .

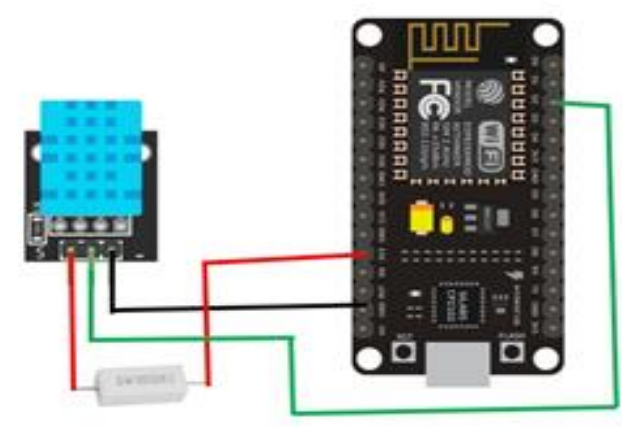

\section{Gambar 7. Skema Perancangan Elektronik}

\subsection{Hasil Akhir}

Setelah melakukan perancangan dan pemasangan komponen, selanjutnya adalah melakukan serangkaian uji coba pada masingmasing blok rangkaian yang bertujuan untuk mendapatkan kesesuaian spesifikasi dan hasil yang diinginkan. Untuk lebih jelas mengenai pembahasan hasil uji coba yang akan dilakukan, dapat beberapa pengujian sebagai berikut :

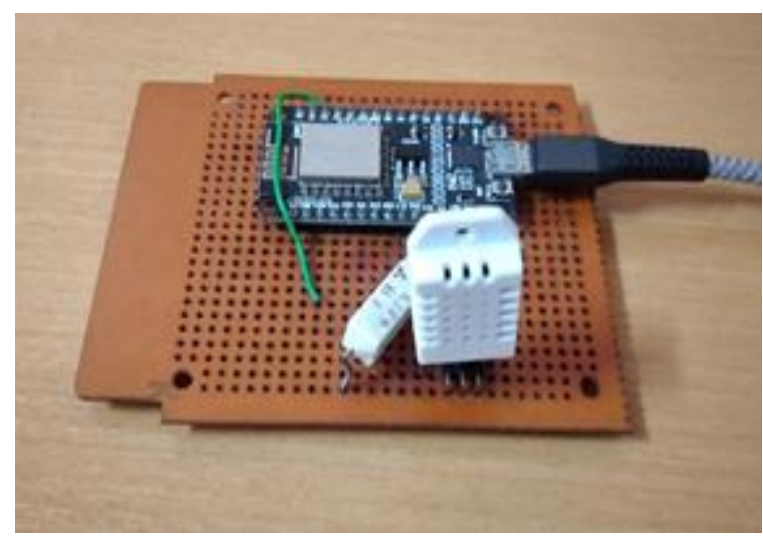

Gambar 8. Hasil akhir alat monitoring suhu
Untuk pengujian sensor suhu DHT 22 dilakukan dengan membandingkan hasil pengukuran sensor DHT22 dengan termometer digital. Pengujian dilakukan dengan cara melakukan pengukuran suhu di beberapa ruangan. Pengambilan suhu dilakukan sebanyak 10 kali dengan interval waktu 1 detik untuk percobaannya bias di lihat di table 1 dan data pengujian suhu dihitung rataratanya untuk membandingkan dengan hasil pengukuran termometer digital.

Tabel 1. Pengujian sensor DHT 22

\begin{tabular}{lcccc}
\hline No & $\begin{array}{c}\text { DHT 22 } \\
\text { /celcius }\end{array}$ & $\begin{array}{c}\text { Termometer } \\
\text { Digital }\end{array}$ & Error & $\begin{array}{c}\text { Rata- } \\
\text { rata } \\
\text { erorr }\end{array}$ \\
\hline 1. & 28.7 & 27.6 & 1.1 & \\
2. & 28.0 & 27.4 & 0.6 & \\
3. & 22.0 & 21.4 & 0.6 & \\
4. & 21.0 & 20.3 & 0.7 & \\
5. & 20.0 & 19.7 & 0.3 & \\
6. & 25.0 & 24.2 & 0.8 & 0.69 \\
7. & 25.0 & 24.4 & 0.6 & \\
8. & 24.0 & 23.2 & 0.8 & \\
9. & 19.0 & 18.2 & 0.8 & \\
10. & 19.0 & 18.4 & 0.6 & \\
\hline
\end{tabular}

Dari 10 kali percobaan didapatkan nilai hasil rata-rata error atau selisih alat monitoring dengan termometer sekitar $0.69^{\circ} \mathrm{C}$.

Adapun cara kerja dari Aplikasi web monitoring suhu ini adalah sebagai berikut :

1) NodeMcu Esp 8266 disambungkan ke Power.

2) Setelah Kondisi nodeMcu ON koneksikan dengan jaringan wifi yang sudah tersambuk oleh jaringan internet.

3) Hasil dari Sensor suhu akan dikirim ke aplikasi web responsive dengan memasukan link ke browser yang telah di tentukan yaitu http://192.168.100.64/arduino-php-native.

Dan nilai suhu yang di tampilkan akan 
tersimpan di dalam database mySql. Sehingga kita dapat mengetahui nilai suhu secara berkala.

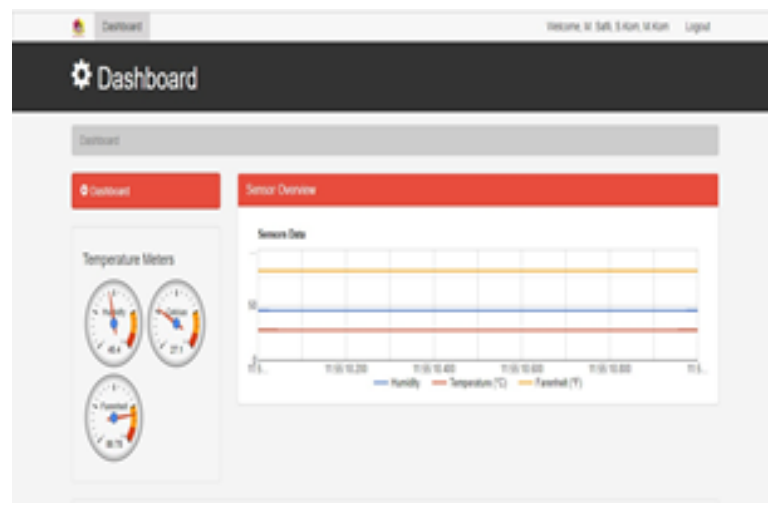

\section{Gambar 9. Tampilan versi Web}

Pada sistem monitoring suhu ini kita dapat mengetahui nilai humandity, celcius dan farenheit. Humandity di gunakan untuk mengetahui nilai kelembapan dalam sebuah objek tertentu. Sedangkan celcius dan Fahrenheit digunakan untuk mengetahui nilai suhu pada objek tertentu.

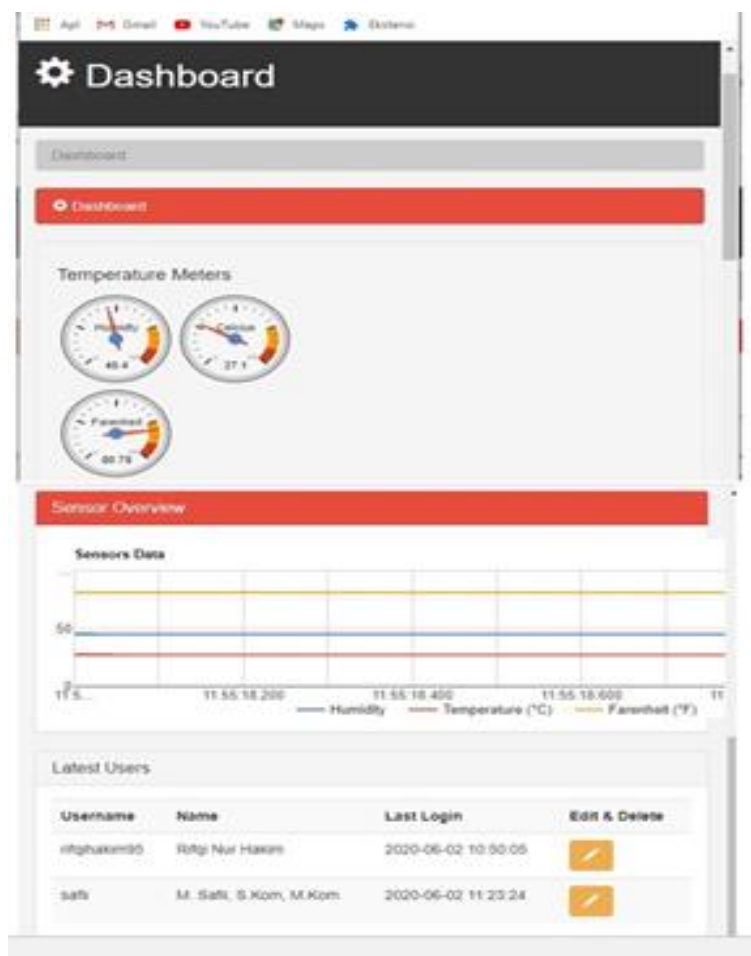

Gambar 10. Tampilan versi android atau smartphone

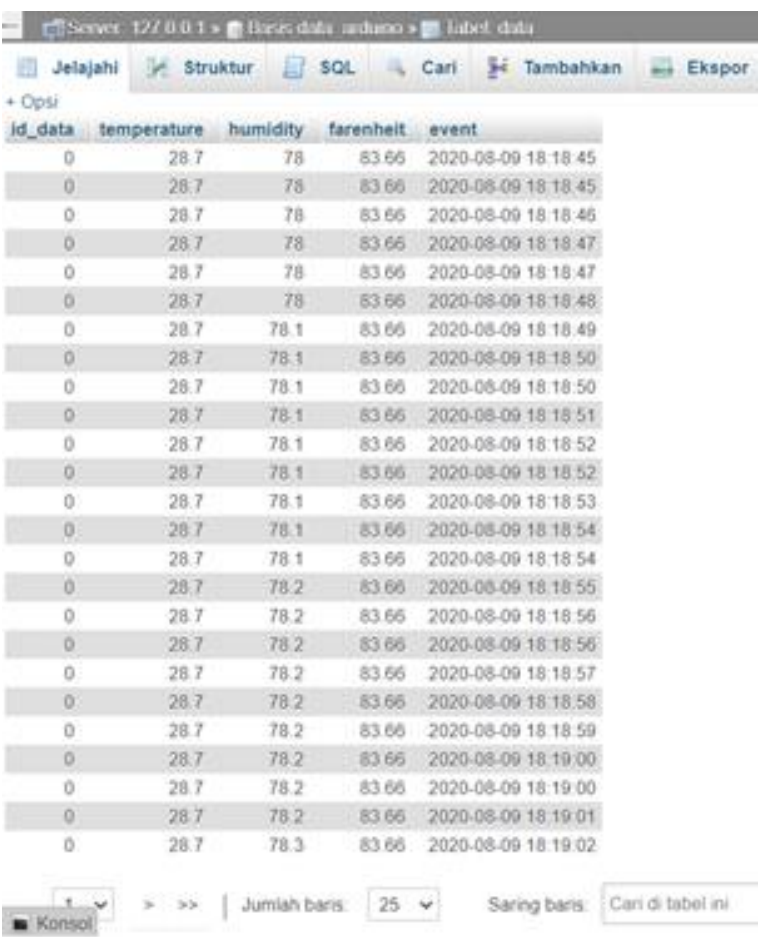

\section{Gambar 11. Database MySql Monitoring Suhu}

Dalam database MySql kita terdapat 5 field yaitu id_data, temperature, humandity, farenheit dan event. Event disini menampilkan data dari nilai suhu secara realtime mulai dari tanggal dan waktu, sehingga nilai informasi yang di tampilkan di aplikasi web akan terpantau terus menerus.

\section{KESIMPULAN}

Basarkan hasil yang telah dicapai dalam penelitian ini, terdapat beberapa kesimpulan, diantaranya :

1. Alat yang di hasilkan berupa monitoring suhu yang di tempatkan di ruang server sehingga petugas dapat secara realtime memantau perkembangan nilai suhu kapan saja.

2. Platform yang digunakan untuk monitoring ini bisa menggunakan PC atau 
smartphone karena aplikasi yang di rancang responsive terhadap semua platform elektronik.

3. Perancangan sistem dibagi menjadi 2 bagian, yaitu : perancangan perangkat keras dan perancangan perangkat lunak.

4. Sistem mampu menjalankan fungsi sesuai dengan hasil analisa kebutuhan.

5. Data yang dikirimkan dari nodeMcu secara terus menerus akan mengirimkan data keserver hal ini akan membuat boros energi yang ada pada node sehingga belum efesien terhadap pengguna energy listrik di sisi node

Pada penelitian ini masih banya kekurangan dan adapun saran yang sebaiknya dikembangkan dalam penelitian berikutnya adalah :

1. Menggunakan MTqq server sehingga bisa di hosting public dan dapat dimonitoring pada jaringan wifi internet yang berbeda.

2. Proses pengumpulan dan pengiriman data akan lebih efesien lagi kalau menerapkan kecerdasan disisi node sensor sehingga kapan waktu pengirim data ke server dan data mana yang dikirimkan sudah ditentukan disisi node.

\section{UCAPAN TERIMA KASIH}

Direktorat Riset dan Pengabdian Masyarakat Direktorat Jenderal Penguatan Riset dan Pengembangan Kementerian Riset, Teknologi, dan Pendidikan Tinggi sesuai dengan Kontrak Penelitian Tahun Anggaran 2020

\section{DAFTAR PUSTAKA}

[1] Republik Indonesia. Rancangan Peraturan Menteri Komunikasi dan Informatika Republik Indonesia. Tentang Standardisasi Infrastruktur Pusat Data, 2018

[2] Reno. Z, "Perancangan monitoring suhu ruangan menggunakan arduino berbasis android di PT. Tunggal idaman abdi cabang Palembang", Jurnal Teknologi Informasi, Lubuklinggau. Vol 8 (2). pp. 29-37K, 2016.

[3] Andrew. M, Sistem monitoring suhu ruang server dengan mikrokontroler arduino berbasis desktop, skripsi Universitas Dipenogoro, Semarang. 2016.

[4] Sawita I. A. S., \& dik. "Alat monitoring suhu melalui aplikasi android menggunakan sensor LM35 dan modul sim8001 berbasis mikrokontroler atmega16", Buletin Fisika. Vol 18 (2) Pp. 58-62. 2018.

[5] Muhammad Safii, "Perancangan Sistem Monitoring Tegangan Output Genset menggunakan Ethernet Shield dan SMS Gateway berbasis Arduino Uno", Jurnal METIK Vol 21, No 1 Pp 46-52, 2019.

[6] Kurnia D.S., \& dkk, Perancangan Prototipe Sistem Kontrol Suhu dan Kelembaban pada Gedung Walet dengan Mikrokontroler Berbasis Mobile, Jurnal Edukasi dan Penelitian Indonesia. Vol 4 (1) pp.36-42. 2018.

[7] Aosong. Temperature and Humidity Module DHT22 Product. Manual. Guangzho: Electronic Co . 2018.

[8] http://www.instructables.com/id/QuickStart-to-Nodemcu-ESP8266onArduinoIDE/ diakses pada 16 Agustus 2019

[9] Riyanto, "Sistem Informasi Penjualan Dengan PHP dan MySQL", Gava Media, Yogyakarta. 2010.

[10] Syahwil, "Teknik Pemrograman Arduino Sederhana". Gramedia: Surabaya. 2013.

[11] Sulindawati, dan Fathoni, M. "Pengantar Analisa Perancangan Sistem" Medan: STMIK Triguna Dharma. 2010. 